\title{
Nitrogen fertilization of winter wheat in spring in Finland: comparison of calcium ammonium nitrate and calcium nitrate, and the effect of split application
}

\author{
OILI MOHAMMADI, LEENA RISTIMÄKI, STEPHAN VERMEULEN \\ and ESKO VIIKARI \\ Kemira Oy, Espoo Research Centre, Luoteisrinne 2, \\ SF-02270 Espoo, Finland
}

\begin{abstract}
The effectiveness of calcium nitrate $(\mathrm{CN})$ and calcium ammonium nitrate (CAN) as $\mathrm{N}$ sources for winter wheat in spring was studied in seven field trials in Southern Finland, in the province of Uusimaa. The experiments were carried out on clay soils in 1986-1989. Nitrogen dressings of $120-150 \mathrm{~kg} \mathrm{ha}^{-1}$ were broadcasted either as a single application or split into two applications. The two applications were in most cases $30-40$ and $90-110 \mathrm{~kg}$ $\mathrm{ha}^{-1}$. The single or the first split application was given in the beginning of the growing season and the latter application at the end of tillering. The grain yields obtained by a single $\mathrm{N}$ application of $140-150 \mathrm{~kg} \mathrm{ha}^{-1}$ ranged from 2610 to $7550 \mathrm{~kg} \mathrm{ha}^{-1}$ and the protein content of grains from 9.4 to $14.5 \%$. The nitrogen form of the fertilizer had no significant effect on the grain yield and on the protein content of grains. Splitting the nitrogen increased the grain yield by $400 \mathrm{~kg} \mathrm{ha}^{-1}$ and the protein content of grains by 0.8 percentage points.
\end{abstract}

Index words: Calcium ammonium nitrate, calcium nitrate, fertilization, nitrogen, split application, winter wheat

\section{Introduction}

Calcium ammonium nitrate (CAN) is the most commonly used straight nitrogen fertilizer in Finland. An amount of 79000 tons of CAN was sold in Finland during the period July 1, 1988 to June 30, 1989 (ANON. 1989). Calcium nitrate $(\mathrm{CN})$ is today of minor importance, 3000 tons being used annually. The nitrogen of $\mathrm{CN}$ is in nitrate form, whereas $\mathrm{CAN}$ contains nitrogen in nitrate and in ammonium form in equal proportions.
There are only few papers comparing the effect of $\mathrm{CN}$ and $\mathrm{CAN}$ on the grain yield of winter cereals in Finland or other Scandinavian countries. JAAKKOLA (1978) compared five forms of fertilizer $\mathrm{N}$ in a five-year field experiment on winter wheat, winter rye and spring wheat; there was no difference in the effect of $\mathrm{CN}$ and $\mathrm{CAN}$ on the grain yield. The effect of $\mathrm{CAN}$ and $\mathrm{CN}$ on the grain yield of winter wheat has been compared also in 
Sweden in a series of 97 trials; $\mathrm{CN}$ was found to be a more effective $\mathrm{N}$ source than CAN in the eastern and in the western part of Sweden, but not in the southern part (JonssON 1971). The rate of nitrogen application in both trials (JAAKKOLA 1978, JoNSSON 1971) was lower (75 and $60 \mathrm{~N} \mathrm{~kg} \mathrm{ha-1,} \mathrm{respectively)} \mathrm{than} \mathrm{used}$ nowadays.

The $\mathrm{N}$ fertilizer dressing of winter cereals in spring is traditionally given in one application in Finland. Splitting the fertilizer dressing into two applications is a common practice in Sweden, where the climatic conditions and the length of the growing period are equal to those in Finland. A low application of $\mathrm{N}$ is given in the beginning of the growing season and the rest of the nitrogen at the tillering stage, if growth is exuberant. If the vegetation is scanty, the higher dose is given first.

The aim of this study was to compare $\mathrm{CN}$ and $\mathrm{CAN}$ in spring fertilization of winter wheat. The effect of a split fertilizer application was also investigated.

\section{Materials and methods}

The seven field experiments reported in this paper were carried out in 1986-1989 in Southern Finland, in the province of Uusimaa. The experimental crop in all trials was the winter wheat cultivar "Aura". The quantity of seeds sown was $220-250 \mathrm{~kg} \mathrm{ha}^{-1}$. Plant-available nutrient resources of the soils were determined before starting the trials by acid ammonium acetate extraction (VUORINEN and MäKITIE 1955). At the time of sowing in
September the experimental fields were given a NPK fertilizer application according to their fertility. The $\mathrm{N}$ application in autumn ranged from 48 to $110 \mathrm{~kg} \mathrm{ha}^{-1}$. Details of the experimental fields and their autumn fertilization are given in Table 1.

In spring the experimental fields were given a $\mathrm{N}$ dressing as calcium nitrate $(15.5 \% \mathrm{~N})$ or calcium ammonium nitrate $(27.5 \% \mathrm{~N})$. The nitrogen dressing was broadcasted on the field either as one application or split into two applications. The first application was given at the beginning of the growing period in late April or in early May. The second application was given at the end of the tillering stage in late May. The rates of fertilizer dressings $(\mathrm{N}$ $\mathrm{kg} \mathrm{ha}^{-1}$ ) were as follows:

$\begin{array}{ccc}\text { Trial 1 } & \begin{array}{c}\text { Beginning of } \\ \text { growing season }\end{array} & \begin{array}{c}\text { End of } \\ \text { tillering }\end{array} \\ & 150 & - \\ \text { Trials 2-7 } & 110 & 40 \\ & 40 & 110 \\ & 120 & - \\ & 30 & 90 \\ & 140 & - \\ 30 & 110\end{array}$

The field of trial 1 was divided into four blocks, each comprising six plots of $60 \mathrm{~m}^{2}$. Trial 3 consisted of two blocks and trials 2, 4, 5, 6 and 7 of three blocks, each comprising 8 plots of $30 \mathrm{~m}^{2}$.

After harvest the grain yields were weighed, the moisture content was determined and the grain yields per hectare were calculated at a moisture level of $15 \%$. The replicate samples

Table 1. Location, soil type and autumn fertilization of the experimental fields.

\begin{tabular}{|c|c|c|c|c|c|}
\hline \multirow[t]{2}{*}{ Trial } & \multirow[t]{2}{*}{ Year } & \multirow[t]{2}{*}{ Location } & \multirow[t]{2}{*}{ Soil type } & \multicolumn{2}{|c|}{ Autumn fertilization } \\
\hline & & & & N-P-K (\%) & $\mathrm{kg} \mathrm{ha}^{-1}$ \\
\hline 1 & 1986 & Kotkaniemi, Vihti & Loamy clay & $16-7-13$ & 500 \\
\hline 2 & 1986 & Sten Ståhls, Loviisa & Sandy clay & $12-11-10$ & 600 \\
\hline 3 & 1987 & Stor Sarvlax, Loviisa & Gyttja clay & $12-11-10$ & 400 \\
\hline 4 & 1988 & Västankvarn, Inkoo & Gyttja clay & $16-7-13$ & 300 \\
\hline 5 & 1989 & Stor Sarvlax, Loviisa & Gyttja clay & $12-11-10$ & 400 \\
\hline 6 & 1989 & Majuri, Vihti & Silty clay & $20-4-8$ & 550 \\
\hline 7 & 1989 & Västankvarn, Inkoo & Gyttja clay & $16-7-13$ & 400 \\
\hline
\end{tabular}


were combined for protein analysis, and the analysis was carried out in duplicate. The grain yield results were tested statistically using the analysis of variance, which was made separately for each trial. The paired t-test was applied for the data of all trials to test the effect of the $\mathrm{N}$ form of the fertilizer, split application and rate of $\mathrm{N}$ dressing on the protein content of grains.

\section{Results and discussion}

The average yields of winter wheat when using $\mathrm{CAN}$ and $\mathrm{CN}$ were $5480 \mathrm{~kg} \mathrm{ha}^{-1}$ and $5380 \mathrm{~kg} \mathrm{ha}^{-1}$, respectively (Table 3). The low yields of 1987 and 1988, ranging from 2430 to $3590 \mathrm{~kg} \mathrm{ha}^{-1}$, were mainly due to the low average temperature in 1987 and the dryness in 1988. The Summers of 1986 and
1989 were beneficial for winter wheat and the yields were relatively high, ranging from 4630 to $8210 \mathrm{~kg} \mathrm{ha}^{-1}$. The low protein contents were typical of high grain yields and vice versa. The protein content of grains ranged from 9.4 to $15.1 \%$ (Table 2).

Raising the rate of $\mathrm{N}$ application from 120 to $140 \mathrm{~kg} \mathrm{ha}^{-1}$ did not have any significant effect on the quantity of grain yields, although it decreased the average yield by $100 \mathrm{~kg} \mathrm{ha}^{-1}$. Increasing the $\mathrm{N}$ application by $20 \mathrm{~kg} \mathrm{ha}^{-1}$ elevated the average protein content of grains by 0.5 percentage points $\left(t=4.60^{* * *}\right)$. The autumn fertilization showed no effect in any trial.

The grain yields obtained with CAN were in five trials slightly higher than those obtained with $\mathrm{CN}$, but the difference was significant only in trial $7\left(\mathrm{~F}=10,27^{* *}\right)$. The type of

Table 2. Grain yield $\left(\mathrm{kg} \mathrm{ha}^{-1}\right)$ and protein content $(\%)$ of grains of winter wheat fertilized with $\mathrm{CAN}$ and $\mathrm{CN}$.

\begin{tabular}{|c|c|c|c|c|c|c|}
\hline \multirow[t]{2}{*}{ Trial } & \multirow[t]{2}{*}{ Year } & \multirow[t]{2}{*}{$\mathrm{N} \mathrm{kg} \mathrm{ha-1}$} & \multicolumn{2}{|c|}{$\begin{array}{l}\text { Grain yield, } \\
\mathrm{kg} \mathrm{ha}^{-1}\end{array}$} & \multicolumn{2}{|c|}{$\begin{array}{c}\text { Protein content } \\
\text { of grains, } \%\end{array}$} \\
\hline & & & CAN & $\mathrm{CN}$ & CAN & $\mathrm{CN}$ \\
\hline 1 & 1986 & $\begin{array}{l}150 \\
110+40 \\
40+110\end{array}$ & $\begin{array}{l}4930 \\
5320 \\
5000\end{array}$ & $\begin{array}{l}4630 \\
4900 \\
4940\end{array}$ & $\begin{array}{l}13.4 \\
13.3 \\
13.9\end{array}$ & $\begin{array}{l}13.6 \\
14.6 \\
14.7\end{array}$ \\
\hline 2 & 1986 & $\begin{array}{l}120 \\
30+90 \\
140 \\
30+110\end{array}$ & $\begin{array}{l}6780 \\
7290 \\
6980 \\
7370\end{array}$ & $\begin{array}{l}6860 \\
7160 \\
6550 \\
7150\end{array}$ & $\begin{array}{l}12.2 \\
14.6 \\
13.7 \\
15.0\end{array}$ & $\begin{array}{l}12.5 \\
13.9 \\
14.1 \\
15.1\end{array}$ \\
\hline 3 & 1987 & $\begin{array}{l}120 \\
30+90 \\
140 \\
30+110\end{array}$ & $\begin{array}{l}2880 \\
3300 \\
2690 \\
3070\end{array}$ & $\begin{array}{l}3120 \\
3590 \\
2730 \\
3070\end{array}$ & $\begin{array}{l}14.7 \\
14.3 \\
14.5 \\
14.8\end{array}$ & $\begin{array}{l}14.4 \\
14.2 \\
14.5 \\
14.9\end{array}$ \\
\hline 4 & 1988 & $\begin{array}{l}120 \\
30+90 \\
140 \\
30+110\end{array}$ & $\begin{array}{l}2710 \\
2910 \\
2600 \\
2560\end{array}$ & $\begin{array}{l}2620 \\
2860 \\
2610 \\
2440\end{array}$ & $\begin{array}{l}12.2 \\
12.0 \\
12.1 \\
11.9\end{array}$ & $\begin{array}{l}12.0 \\
12.0 \\
12.1 \\
12.1\end{array}$ \\
\hline 5 & 1989 & $\begin{array}{l}120 \\
30+90 \\
140 \\
30+110\end{array}$ & $\begin{array}{l}7220 \\
7710 \\
7230 \\
7880\end{array}$ & $\begin{array}{l}7430 \\
7720 \\
7550 \\
8210\end{array}$ & $\begin{array}{r}9.8 \\
10.2 \\
9.9 \\
10.8\end{array}$ & $\begin{array}{r}9.4 \\
9.5 \\
9.4 \\
10.3\end{array}$ \\
\hline 6 & 1989 & $\begin{array}{l}120 \\
30+90 \\
140 \\
30+110\end{array}$ & $\begin{array}{l}6250 \\
6740 \\
6430 \\
6410\end{array}$ & $\begin{array}{l}6300 \\
6700 \\
6170 \\
6460\end{array}$ & $\begin{array}{l}10.6 \\
11.3 \\
12.2 \\
11.3\end{array}$ & $\begin{array}{l}11.3 \\
11.6 \\
11.8 \\
12.5\end{array}$ \\
\hline 7 & 1989 & $\begin{array}{l}120 \\
30+90 \\
140 \\
30+110\end{array}$ & $\begin{array}{l}5190 \\
6470 \\
5010 \\
6170\end{array}$ & $\begin{array}{l}4680 \\
5830 \\
4720 \\
5940\end{array}$ & $\begin{array}{r}9.4 \\
13.0 \\
10.1 \\
13.0\end{array}$ & $\begin{array}{r}9.9 \\
11.3 \\
10.8 \\
12.0\end{array}$ \\
\hline
\end{tabular}




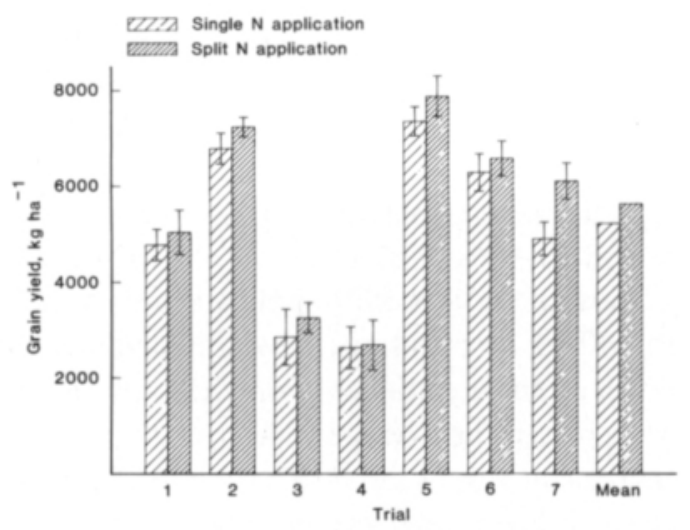

Fig. 1. Grain yields of winter wheat fertilized by single and split $\mathrm{N}$ dressing in seven $(1-7)$ field trials.

$\mathrm{N}$ fertilizer did not affect the protein content of grains. The average protein content obtained with $\mathrm{CN}$ and CAN was $12.4 \%$. JAAKKOLA's (1978) results of a five-year field trial also indicated that there was no significant difference in the size of grain yield or in the protein content of grains when winter wheat and winter rye were fertilized with $\mathrm{CN}$ or CAN. According to Esala (1989), CN and $\mathrm{CAN}$ were also equal $\mathrm{N}$ sources as the second $\mathrm{N}$ dressing for spring wheat. Because of the fast-acting nitrate (TISDALE et al. 1985), CN is claimed to be a useful fertilizer for winter cereals in spring. The present results do not, however, distinguish between the effectiveness of $\mathrm{CN}$ and CAN.

Splitting the fertilizer dressing into two ap-

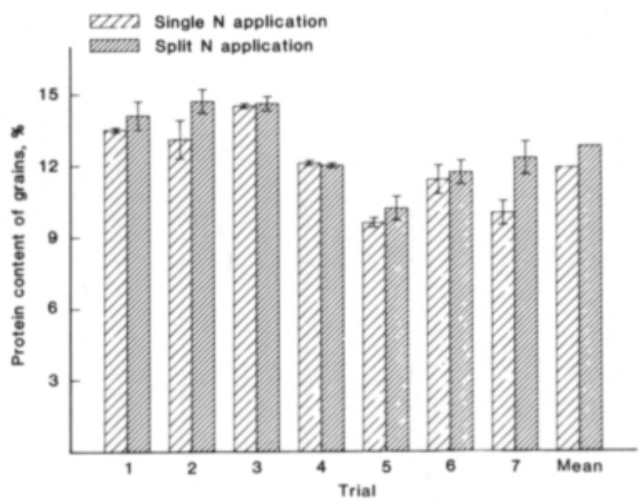

Fig. 2. Protein content of grains of winter wheat fertilized by single and split $\mathrm{N}$ dressing in seven $(1-7)$ field trials. plications increased the grain yields by $2-25$ $\%$ (Fig. 1); the difference was $400 \mathrm{~kg} \mathrm{ha}^{-1}$ on average. The split application affected similarly the yields obtained with $\mathrm{CN}$ and CAN. The increase of grain yield was statistically significant in trial $2\left(\mathrm{~F}=15.85^{* *}\right)$, trial $5\left(\mathrm{~F}=11.93^{* *}\right)$ and trial $7\left(\mathrm{~F}=84.25^{* * *}\right)$. Split application of $\mathrm{N}$ increased the protein content of grains in all trials except trial 3 (Fig. 2). The maximum increase of 2.3 percentage points was obtained in trial 7. The increase of the protein content was 0.8 percentage points on average $\left(\mathrm{t}=3.71^{* *}\right)$, which is noteworthy as the protein content of winter wheat is low, as compared to spring wheat.

Based on three field experiments, VARIS and JuUTI (1975) reported that splitting a N dressing of $100 \mathrm{~kg} \mathrm{ha}^{-1}$ into two applications in spring increased both the quantity and protein content of grain yield of winter wheat. The present results, which are based on more extensive material, were in agreement with their observations. Inversely, RAININKO (1966) did not obtain higher yields by giving an additional $\mathrm{N}$ dressing of 25 or $50 \mathrm{~kg} \mathrm{ha}^{-1}$ to wheat at the flowering stage. The grain yield of winter rye increased in a Danish field trial when a $\mathrm{N}$ application of 200 or $300 \mathrm{~kg} \mathrm{ha}^{-1}$ was split in spring, while splitting a $\mathrm{N}$ application of $100 \mathrm{~kg} \mathrm{ha}^{-1}$ had a negative effect (OlsEn 1986). Indeed, VARIS and JuUti (1975) suggested that splitting the $\mathrm{N}$ application of winter cereals is beneficial only if relatively high amounts of nitrogen are used. A large amount of $\mathrm{N}$ in the beginning of the growing season increases the vegetative growth too much, which can disturb later growth by causing lodging, by shadowing the lower leaves and by spending the plant-available nutrient resources of the soil in too early a growth stage. These negative effects can be prevented by splitting the $\mathrm{N}$ dressing, which guarantees a more steady availability of $\mathrm{N}$ during the growing season.

All trials reported in this paper were carried out on clay soils. According to the results of Danish field experiments, winter wheat can benefit even more from splitting the $\mathrm{N}$ dress- 
ing when grown on coarse soil, because nitrogen is more readily leached from sandy soils than from clay soils (OLSEN and LARSEN 1984). Furthermore, Gregersen and HeJLESEN (1985) found that higher winter wheat yields can be obtained on sandy soils if the nitrogen dressing is split into three applications instead of two.

According to the present results, a $\mathrm{N}$ dressing of $120 \mathrm{~kg} \mathrm{ha}^{-1}$ can be considered sufficient for winter wheat. Raising the amount of $\mathrm{N}$ by $20 \mathrm{~kg} \mathrm{ha}^{-1}$ did not further increase the grain yield, even though the protein content increased by 0.5 percentage points. Splitting the $\mathrm{N}$ application into two parts was a more effective way of increasing the size and the protein content of the yield than was the use of an increased single application. There was no difference in the size of the yield and the protein content of grains whether $\mathrm{CN}$ or $\mathrm{CAN}$ was used. However, the use of CAN is more economical, because the $\mathrm{N}$ content of $\mathrm{CN}$ $(15.5 \%)$ is considerably lower than that of CAN (27.5\%), resulting in higher transportation, storage and broadcasting costs when using $\mathrm{CN}$, as compared to CAN. Furthermore, $\mathrm{CN}$ is extremely hygroscopic and this property makes $\mathrm{CN}$ a less attractive fertilizer (Tisdale et al. 1985).

\section{References}

ANON. 1989. Lannoitteiden myynnin jakautuminen maatalouskeskusalueittain lannoitusvuonna 1988/89. 20 p. Kemira Oy, Helsinki.

EsALA, M. 1989. Kevătvehnăn valkuaispitoisuuden lisăäminen. Kylvömies 1/1989 p. 6-8.

Gregersen, A.K. \& Hejlesen E. 1985. Vand og kvaelstof til vinterhvede på sandjord. Summary: Irrigation and application of nitrogen to winter wheat on sandy soil. Tidsskr. Planteavl 89: 231-240.

JAAKKOLA, A. 1978. Nitrate, ammonium and urea nitrogen fertilizers for wheat and rye in a field experiment. J. Scient. Agric. Soc. Finl. 50: 346-360.

Jonsson, L. 1971. Urea som gődselmedel. Hőstsăd. Lantbrukshögskolans meddelanden A 147. 28 p. Uppsala.

OLSEN, C.C. 1986. Optimeret udnyttelse af vinterruggens udbytteevne. Meddelelse nr. 1888. Statens Planteavlsforsoeg, Lyngby, Danmark. 4 p.

OlsEn, C.C. \& LARSEN, K.E. 1984. Kvaelstof til vinterhvede, engangs- eller delt udbringing. Summary:
Nitrogen application to winter wheat, single or split dressing. Tidsskr. Planteavl. 88: 243-255.

RAININKo, K. 1966. Myőhăisen typpilannoituksen vaikutus kevătvehnăn satoon ja leivinominaisuuksiin. Summary: Influence of late nitrogen fertilization on the quality of wheat. J. Scient. Agric. Soc. Finl. 38: $140-149$.

Tisdale, S.L., Nelson, W.L. \& Beaton, J.D. 1985. Soil fertility and fertilizers. 754 p. 4th Ed. New York.

VARIS, E. \& JuUtı, T. 1975. Syysvehnăn typpilannoituksen ajoittamisesta. Summary: Timing of nitrogen application in winter wheat production. J. Scient. Agric. Soc. Finl. 47: 270-282.

Vuorinen, J. \& Măkıtie, O. 1955. The method of soil testing in use in Finland. Agrogeol. Publ. 63. 44 p. Helsinki.

Ms received 11.1 .90 


\title{
SELOSTUS
}

\section{Syysvehnän kevätlannoitus: Kalkkisalpietarin ja oulunsalpietarin vertailu sekä jaetun typpilannoituksen vaikutus}

\author{
Oili Mohammadi, Leena Ristimäki, \\ Stephan Vermeulen ja Esko Viikari
}

Kalkkisalpietarin ja oulunsalpietarin tehokkuutta syysvehnăn kevăttyppilannoituksessa tutkittiin 7 kenttăkokeen sarjassa Uudellamaalla vuosina 1986-1989. Koekenttien maalaji oli hiesu-, hieta-, hiue- tai liejusavea. Typpilannoite-erăt, jotka sisălsivăt typpeă $120-150 \mathrm{~kg} \mathrm{ha}^{-1}$, levitettiin koeruuduille joko kertalannoituksena kasvukauden alussa tai jaettuna kahteen osaan, joista ensimmäinen, (tavallisimmin 30-40 $\mathrm{kg} \mathrm{ha}^{-1}$ ) annettiin kasvukau- den alussa ja jälkimmäinen $\left(90-110 \mathrm{~kg} \mathrm{ha}^{-1}\right)$ versomisvaiheen lopussa. Jyvăsato vaihteli $2610-7550 \mathrm{~kg} \mathrm{ha}^{-1}$ ja jyvien valkuaispitoisuus $9.4-14.5 \%$ ruuduissa, joille oli annettu typpeả $140-150 \mathrm{~kg} \mathrm{ha}^{-1}$ kertalannoituksena. Typpilannoitelaji ei vaikuttanut jyvăsadon măäräăn tai valkuaispitoisuuteen. Jaettu typpilannoitus suurensi hehtaarisatoa keskimäărin $400 \mathrm{~kg}$ ja jyvien valkuaispitoisuutta 0.8 prosenttiyksikköă. 